\title{
Pengembangan Media Pembelajaran Video Interaktif Berbasis Power Director pada Materi Luas Segitiga
}

\author{
Alfi 'Inayatul Firdaus ${ }^{1}$, Ummu Sholihah \\ ${ }^{1}$ UIN Sayyid Ali Rahmatullah \\ 12alfiinaya98@gmail.com
}

\begin{tabular}{l}
\hline \hline Article Info \\
\hline Article history: \\
Received Oct $21^{\text {th }} 2021$ \\
Revised Nov $17^{\text {th }} 2021$ \\
Accepted Nov $23^{\text {th }} 2021$ \\
\hline
\end{tabular}

Keywords:

Learning Media;

Power Director;

Triangle Problem

Abstract
This study aims to determine the validity and
effectiveness of interactive video learning media based
on Power Director in the area of the triangle material.
The research approach used is the Research and
Development (RnD) approach with the ADDIE (Analyze,
Design, Development, Implementation, Evaluation)
development model. The subjects in this study were class
$X$-TOT 1 (control class) and class X-TOT 2
(Experimental Class). Methods of data collection using
questionnaires and tests. Questionnaires were used to
obtain media validity data and tests were used to
determine the effectiveness of using media. The results
showed that the Power Director-based interactive video
learning media was valid for use with a media validity
value of 3.02 and a material validity value of 3.7. The
results of the t-test calculation carried out obtained a
value of 0.001 <0.05 which indicates that there is a
significant difference between the control class and the
experimental class in the use of Power Director-based
learning media. So, Power Director-based interactive
video learning media is effectively used because it can
improve student learning outcomes in solving the area of
the triangle problem.

Kata Kunci:

Media Pembelajaran;

Power Director;

Luas Segitiga;

\section{Abstrak}

Penelitian ini bertujuan untuk mengetahui validitas dan efektivitas media pembelajaran video interaktif berbasis Power Director pada materi Luas Segitiga. Pendekatan penelitian yang digunakan adalah pendekatan Research and Developement $(\mathrm{RnD})$ dengan model pengembangan ADDIE (Analyze, Design, Development, Implementation, Evaluation). Subjek dalam penelitian 
ini yaitu kelas X-TOT 1 (kelas kontrol) dan kelas $\mathrm{X}$ TOT 2 (kelas eksperimen). Metode pengumpulan data menggunakan angket dan tes. Angket digunakan untuk memperoleh data validitas media dan tes digunakan untuk mengetahui efektivitas penggunaan media. Hasil penelitian menunjukkan bahwa media pembelajaran video interaktif berbasis Power Director valid untuk digunakan dengan nilai validitas media 3,02 dan nilai validitas materi sebesar 3,7. Hasil perhitungan uji-t yang dilakukan diperoleh nilai $0,001<0,05$ yang menunjukkan bahwa ada perbedaan yang signifikan kelas kontrol dan kelas eksperimen pada penggunaan media pembelajaran berbasis Power Director. Jadi, media pembelajaran video interaktif berbasis Power Director efektif digunakan karena dapat meningkatkan hasil belajar siswa dalam menyelesaikan masalah luas segitiga.

\section{PENDAHULUAN}

Munculnya istilah Revolusi Industri 4.0 di abad 21 yang ditandai dengan masifnya perkembangan teknologi dan informasi yang begitu pesat (Cahdriyana \& Richardo, 2020). Kemajuan teknologi membuat manusia secara sengaja maupun secara tidak sengaja telah dan akan selalu berinteraksi terhadap teknologi. Media elektronik sebagai akibat dari perkembangan teknologi, mendapat tempat dan perhatian yang cukup besar bagi para peserta didik dan besar pengaruhnya terhadap perkembangan pendidikan (Muhasim, 2017). Oleh karena itu, hal tersebut menuntut dunia pendidikan agar mampu mendesain kurikulum dan pembelajaran yang berkualitas sehingga peserta didik memiliki keterampilan agar dapat berdaya saing secara global. Manfaat kemajuan ilmu dan teknologi dalam aktivitas pembelajaran adalah diharapkan agar siswa dapat mencari sendiri dan langsung mengalami proses belajar. Belajar yang dimaksud berupa pembelajaran yang dilaksanakan secara realistik dan konkrit, sehingga dapat mengembangkan pemahaman dan 
kemampuan berpikir kritis serta menghindari terjadinya verbalisme yang terus-menerus (Elsyam et al., 2019).

Saat ini, belajar sendiri mengalami hambatan yang cukup besar. Dikarenakan dunia saat ini sedang dilanda pandemi Covid-19, begitupun negara kita Indonesia juga sedang mengalaminya. Untuk memutus rantai penularan pandemi Covid-19 tersebut pemerintah masing-masing negara membuat kebijakan untuk menutup negaranya (lockdown) dan tidak memperbolehkan warga untuk berkumpul di tempat keramaian. Diantaranya sekolah-sekolah, lembaga pemerintahan maupun lembaga swasta ditutup untuk sementara agar pandemi segera berakhir. Sesuai dengan UU No. 06/2018, menyebutkan bahwa "Presiden meminta seluruh komponen bangsa untuk melakukan pembatasan kegiatan". Salah satu bentuk pembatasan kegiatan tersebut adalah tidak boleh dilaksanakannya kegiatan belajar mengajar secara tatap muka atau pembelajaran di kelas. Salah satu cara untuk mengatasi hal tersebut, mulai dilaksanakan pembelajaran melalui daring. Pembelajaran dengan cara daring dilaksanakan melalui Whatsapp Group, Zoom, dan aplikasi lainnya. Namun hal ini membuat siswa merasa bosan karena merasa tidak ada variasi dalam pembelajaran.

Penyampaian materi ajar yang tidak bervariasi tidak dapat merangsang siswa dalam proses pembelajaran, sehingga tidak tercapainya tujuan pembelajaran yang diinginkan (Nurrita, 2019). Sehingga diharapkan, ada pembaharuan atau variasi dalam pembelajaran seiring dengan kondisi negara kita yang sedang mengalami pandemi seperti sekarang ini. Dengan adanya variasi dalam pembelajaran diharapkan siswa dapat berbuat sendiri yang pada akhirnya akan mengembangkan seluruh aspek pribadi, sehingga dapat menjadi individu-individu yang kreatif.

Dalam meningkatkan segala aspek kemampuan siswa, media pembelajaran sangat berperan penting, sebagaimana yang diungkapkan Conny R. Semiawan, bahwa pembelajaran yang efektif dan efesien adalah pembelajaran yang dapat mengembangkan sikap belajar individu untuk mewujudkan pribadi yang tidak hanya menguasai pengetahuan dan keterampilan dalam alih ilmu dan teknologi, tetapi juga dapat 
mengembangkan dirinya berdasarkan potensi, bakat dan minatnya menjadi pribadi yang kreatif dan berintegritas tinggi (Fathoni \& Budiman, 2017).

Salah satu cara menciptakan pembelajaran yang efektif dan efisien adalah dengan menggunakan media pembelajaran. Media pembelajaran yang baik sesuai dengan pernyataan Edgar Dale adalah media yang paling nyata yaitu pengalaman langsung, namun pengalaman langsung ini terkadang pada saat proses pembelajaran terhalang oleh waktu untuk menuju lingkungan yang mengambarkan bentuk asli pesan tersebut. Untuk itu, pendidik bisa mengantisipasinya dengan cara memanfaatkan media pembelajaran yang bisa mewaikili itu. Diantaranya, dengan memanfaatkan media audio-visual atau media video (Cahdriyana \& Richardo, 2020). Media video dapat memberikan gambaran suatu objek yang bergerak diiringi dengan suara yang sesuai. Video dapat memberikan informasi, memaparkan proses, menjelaskan konsep-konsep yang sederhana sampai yang rumit, mengajarkan keterampilan, menyingkat atau memperpanjang waktu, dan mempengaruhi sikap siswa. Dengan memanfaatkan media video, proses pembelajaran bisa lebih efektif dan efisien di dalam maupun di luar ruang kelas.

Salah satu bentuk media pembelajaran berupa video, yaitu menggunakan Power Director. Power Director merupakan suatu perangkat lunak pengeditan video yang dikembangkan oleh Cyberlink (Wikipedia). Cyberlink Power Director tersebut adalah sebuah program yang ditujukan kepada para desainer maupun programmer yang bermaksud merancang sebuah video (Cahdriyana \& Richardo, 2020). Media ini dibuat dengan menyesuaikan pada kebutuhan peserta didik dan menyampaikan konsep pembelajaran dengan efektif dan efisien serta dapat menambah pengetahuan dan motivasi serta minat terhadap pembelajaran matematika. Pengembangan video berbasis Power Director pada pembelajaran matematika merupakan salah satu media pembelajaran yang baik untuk digunakan di sekolah, apalagi pada kondisi pembelajaran saat ini. Dimana guru tidak bisa bertemu secara langsung dengan peserta didik untuk memberikan pembelajaran dikarenakan pandemi. 
Kegunaan Power Director ini dapat dijadikan media yang dapat membantu dalam proses pembelajaran matematika, khususnya materi Luas Segitiga Trigonometri. Dengan menggunakan media ini, diharapkan dapat menjadikan variasi pembelajaran yang tidak monoton kepada siswa, karena siswa tidak harus selalu mendengarkan penjelasan guru secara virtual, namun siswa dapat menyimak dan memahami materi dalam video dengan baik.

Hasil pengembangan video pembelajaran menunjukkan bahwa video berbasis Power Director dapat mendorong pencapaian hasil belajar siswa secara maksimal serta dapat mengurangi kesulitan guru dalam proses pembelajaran secara daring ataupun luring (Ilsa et al., 2021). Hal ini juga dikarenakan aplikasi Cyberlink Power Director mudah digunakan dalam mengedit video pembelajaran. Di dalamnya menyediakan fitur-fitur yang menarik serta efek yang sangat beragam yang bisa ditambahkan pada video pembelajaran supaya lebih menarik sehingga dapat menambah minat belajar siswa.

Langkah awal yang harus disiapkan dalam pembuatan media ini adalah menyiapkan aplikasi Power Director beserta materi yang akan disajikan. Dalam proses pembuatannya diperlukan kreativitas dalam menggunakan beragam fitur-fitur yang ada di dalamnya, agar media lebih menarik dan mudah dipahami. Setelah semua materi tersusun dengan baik, dilakukan pengisian suara agar media lebih interaktif dan menambah penjelasan siswa.

Melalui media ini, diharapkan agar dapat membantu pendidik untuk menyampaikan materi luas segitiga lebih menarik dan mudah dipahami, sehingga membuat proses pembelajaran dapat menjadi lebih menyenangkan dan tidak membosankan serta disukai bagi peserta didik.

\section{METODE PENELITIAN}

Penelitian ini merupakan jenis penelitian pengembangan atau disebut sebagai penelitian Research and Development $(\mathrm{RnD})$ dengan pengembangan model ADDIE (Analyze, Design, Development, Implementation, Evaluation) (Tegeh dan Kirna, 2010). Pada tahap analysis dilakukan kegiatan yaitu menentukan materi, analisis KI dan KD, 
analisis kebutuhan media, dan analisis kondisi lapangan. Pada tahap design kegiatan yang dilakukan adalah menyusun rancangan produk, menyesuaikan materi dengan tujuan media, dan perancangan media. Pada tahap development dilakukan kegiatan pengumpulan materi, pembuatan media pembelajaran, pengujian media, dan validasi media. Pada tahap implementation kegiatan yang dilakukan adalah melakukan uji coba lapangan terhadap multimedia interaktif berbasis Power Director yang telah dikembangkan. Pada tahap evaluation, kegiatan yang dilakukan adalah memperbaiki produk yang telah dilakukan uji coba lapangan dan membuat produk akhir berupa media pembelajaran interaktif berbasis Power Director pada materi luas segitiga.

Subjek dalam penelitian ini adalah kelas 10 TOT 1 dan TOT 2 SMKN 2 Tulungagung sebanyak 79 siswa, dimana kelas 10 TOT 1 adalah kelas kontrol dan kelas 10 TOT 2 adalah kelas eksperimen yang menggunakan media pembelajaran video interaktif berbasis Power Director. Materi yang diujikan yaitu materi luas segitiga pada bab trigonometri.

Teknik pengumpulan data dalam penelitian ini menggunakan angket dan tes. Instrumen angket digunakan untuk mengetahui kevalidan media pembelajaran video interaktif berbasis Power Director sedangkan instrumen tes digunakan untuk menilai keefektifan penggunaan media pembelajaran tersebut. Validasi media berbasis Power Director ini dilakukan oleh seorang ahli media, sedangkan validasi tes dilakukan oleh 2 (dua) orang guru mata pelajaran Matematika SMKN 2 Tulungagung.

Penghitungan skor untuk menentukan kevalidan instrumen media pembelajaran berbasis Power Director ini mengikuti langkah-langkah Hobri (Hobri, 2010). Hasil validasi yang terdapat dalam lembar validasi media pembelajaran akan dihitung dan dianalisis menggunakan rumus berikut:

$$
V_{\alpha}=\frac{\sum_{i=1}^{n} l_{i}}{m}
$$

Keterangan:

$V_{a}$ : skor rata-rata total semua aspek 
$l_{i} \quad$ : rata-rata skor untuk aspek ke- $i$

$m$ : banyaknya aspek

Kriteria interpretasi skor validitas media pembelajaran adalah disajikan dalam Tabel 1 berikut.

Tabel 1 Kriteria Kevalidan Instrumen

\begin{tabular}{ccc}
\hline No & Interval & Kriteria Kevalidan \\
\hline 1 & $1 \leq \mathrm{Va} \leq 2$ & Tidak Valid \\
\hline 2 & $2 \leq \mathrm{Va} \leq 3$ & Cukup Valid \\
\hline 3 & $3 \leq \mathrm{Va} \leq 4$ & Valid \\
\hline
\end{tabular}

Tingkat keefektifan media pembelajaran berbasis Power Director ini dapat dilihat dari hasil tes kelas kontrol dan kelas eksperimen. Analisis ini dilakukan menggunakan program IBM SPSS versi 16. Setelah hasil tes diperoleh, dilakukan uji prasyarat yaitu uji normalitas dan homogenitas. Selanjutnya, dilakukan uji- $t$ dengan taraf signifikansi $5 \%$.

\section{HASIL PENELITIAN DAN PEMBAHASAN}

Penelitian ini menghasilkan output berupa media pembelajaran video interaktif berbasis Power Director pada materi luas segitiga yang dapat digunakan untuk membantu proses belajar siswa. Hasil angket validasi media pembelajaran berbasis Power Director disajikan pada diagram berikut.

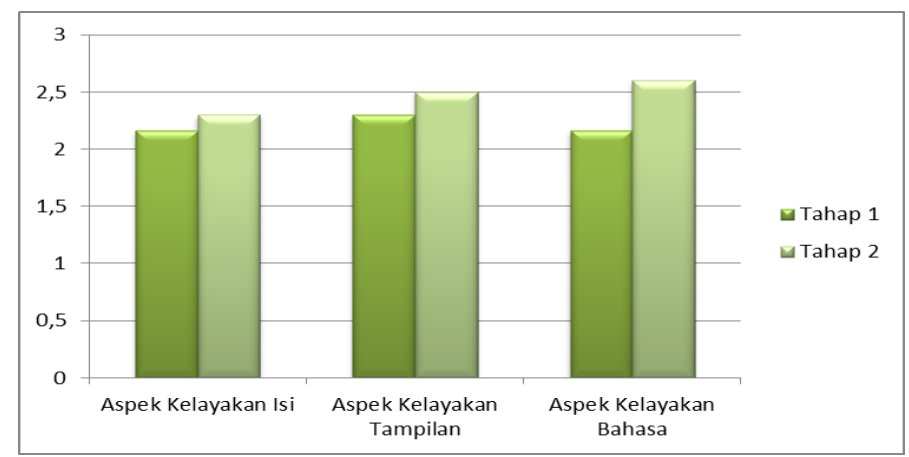

Gambar 1. Diagram Perbandingan Hasil Validasi Ahli Media Tahap 1 dan Tahap 2 
Hasil validasi media tahap pertama mendapat skor rata-rata 2,35, berdasarkan kriteria Hobri, media berada pada kategori "Cukup Valid". Setelah melakukan revisi produk, validasi dilakukan kembali sehingga mendapat skor 3,02 dengan kategori "Valid". Hal tersebut menunjukkan bahwa ada peningkatan skor dari revisi produk. Tabel hasil validasi oleh ahli materi digambar pada diagram Gambar 2.

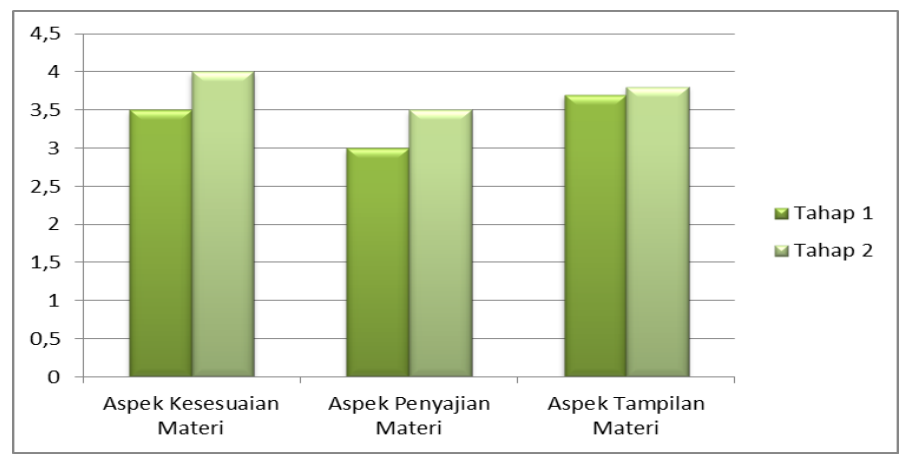

\section{Gambar 2. Diagram Perbandingan Hasil Validasi Ahli Materi Tahap 1 dan Tahap 2}

Hasil validasi materi tahap pertama mendapat skor rata-rata 3,4, berdasarkan kriteria Hobri, media berada pada kategori "Valid". Setelah melakukan revisi produk, validasi dilakukan kembali sehingga mendapat skor 3,7 dengan kategori "Valid". Berdasarkan penilaian validitas kedua aspek tersebut, dapat disimpulkan bahwa media pembelajaran video interaktif berbasis Power Director pada materi luas segitiga memenuhi aspek validitas dalam pengembangan media.

Untuk menguji efektifitas penggunaan media berbasis Power Director dilakukan analisis data secara deskriptif menggunakan aplikasi SPSS versi 16 dari hasil tes dalam menyelesaikan soal luas segitiga pada kelas kontrol dan kelas eksperimen.

Pada tahap pertama dilakukan uji normalitas terlebih dahulu pada kedua kelas tersebut. Hasil uji normalitas dapat dilihat pada Tabel 2 berikut. 
Tabel 2. Hasil Uji Normalitas Kelas Kontrol dan Kelas Eksperimen

Tests of Normality

\begin{tabular}{lcccccccc}
\hline & & \multicolumn{3}{c}{ Kolmogorov-Smirnov $^{\mathrm{a}}$} & \multicolumn{4}{c}{ Shapiro-Wilk } \\
\cline { 3 - 10 } & Kelas & Statistic & $d f$ & Sig. & Statistic & $d f$ & \multicolumn{1}{c}{ Sig. } \\
\hline Hasil & 1 & .133 & 39 & .080 & .968 & 39 & .314 \\
\cline { 2 - 10 } & 2 & .174 & 40 & .004 & .954 & 40 & .107 \\
\hline
\end{tabular}

${ }^{\mathrm{a}}$ Lilliefors Significance Correction

Berdasarkan Tabel tersebut, diperoleh taraf signifikansi sebesar 0,314 pada kelas kontrol dan 0,107 pada kelas eksperimen. Karena taraf siginifikansi kedua kelas tersebut lebih dari 0,05, maka dapat disimpulkan bahwa data tersebut berdistribusi normal.

Selanjutnya, dilakukan uji beda untuk mengetahui perbedaan nilai tes dari kelas kontrol dan eksperimen dalam menyelesaikan soal luas segitiga. Hasilnya dapat dilihat pada Tabel 3 berikut.

Tabel 3 Hasil Uji Beda Kelas Kontrol dan Kelas Eksperimen

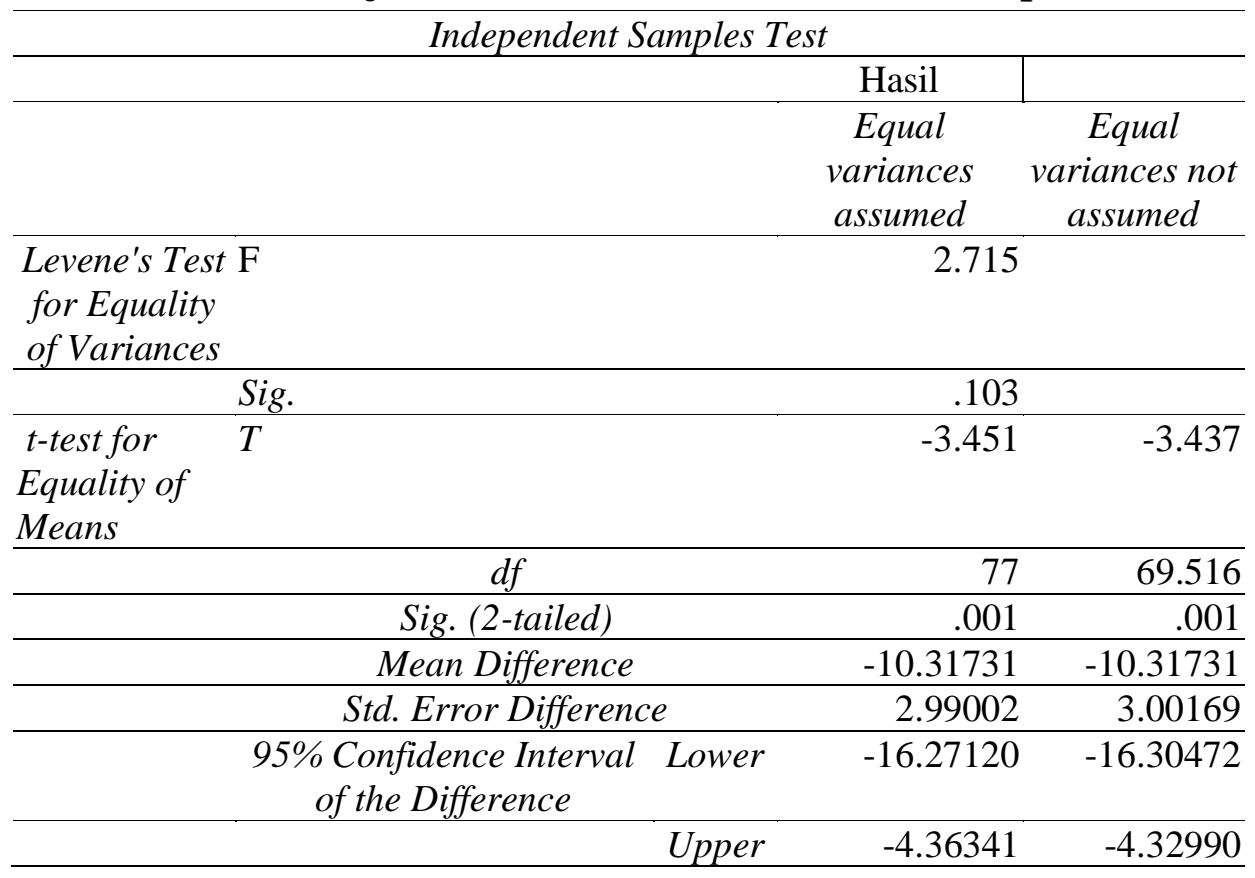


Dari perhitungan di atas diperoleh nilai taraf signifikansi sebesar $0,001<0.05$, maka sebagai dasar pengambilan keputusan dalam uji tersebut dapat disimpulkan bahwa ada perbedaan yang signifikan kelas yang menggunakan media pembelajaran video interaktif berbasis Power Director pada materi luas segitiga dengan yang tidak menggunakan media pembelajaran tersebut. Selanjutnya, pada tabel tersebut ditunjukkan Mean Difference sebesar -10,317331 yang menunjukkan selisih rata-rata hasil tes kelas kontrol dan kelas eksperimen.

Keefektifan terhadap media yang dikembangkan diperoleh berdasarkan nilai tes siswa setelah diberikan media. Pada Tabel 3, menunjukkan ada perbedaan antara siswa yang belajar dengan diberikan media Power Director dan tidak diberikan. Hal ini sejalan dengan pendapat Onansya, penggunaan media yang variatif dalam proses pembelajaran dapat berpengaruh positif terhadap prestasi siswa karena siswa dapat memiliki motivasi yang tinggi dalam belajar sehingga mampu memahami konsep yang diajarkan (Nomleni \& Manu, 2018).

Pada pembelajaran sebelumnya, karena kondisi belajar di masa pandemi, mereka hanya diberikan buku dan saat pemberian tugas, siswa harus memahami materi tersebut secara mandiri atau diterangkan guru melalui proses pembelajaran daring, namun banyak siswa yang jenuh dan kurang dapat memahami penjelasan dari guru. Sehingga, untuk mengatasi hal tersebut, diberikan media Power Director untuk menambah variasi belajar. Ahmad berpendapat bahwa sesuai dengan penelitiannya penggunaan media dalam pembelajaran memberikan sumbangsih yang berharga bagi kualitas belajar siswa serta hasil belajar siswa (Nurfa, 2012).

Di dalam video tersebut, dijelaskan materi luas segitiga secara interaktif. Dilengkapi berbagai ilustrasi gambar, penjelasan, serta contoh soal. Di akhir video, siswa diberikan soal-soal latihan untuk menguji pemahaman mereka mengenai materi luas segitiga. Berbeda dengan kelas kontrol atau kelas yang tidak diberikan video pembelajaran interaktif berbasis Power Director, siswa pada kelas ini hanya diminta guru membaca buku yang telah diberikan dan sesi pertanyaan apabila ada yang 
belum jelas melalui grup whatsapp, sehingga banyak siswa yang kurang aktif bahkan tidak mau bertanya.

Pada saat proses pengamatan video, siswa juga diminta untuk mencermati dengan baik, setelah itu juga diberikan kesempatan bertanya jika ada yang belum dipahami atau belum jelas. Namun, hanya beberapa siswa saja yang mengajukan pertanyaan melalui media whatsapp. Setelah proses pemberian video dan sesi tanya jawab, siswa diberikan soal latihan untuk dikerjakan. Soal yang serupa juga diberikan kepada siswa kelas kontrol. Hasilnya, rata-rata nilai yang dicapai oleh kelas eksperimen lebih tinggi daripada kelas kontrol. Video pembelajaran yang interaktif dapat mendorong pencapaian hasil belajar siswa sehingga dapat mengurangi kesulitan-kesulitan dalam proses pembelajaran (Ilsa et al., 2021).

Berdasarkan hasil pengerjaan soal siswa dan analisis data dengan perbandingan rata-rata hasil tes menunjukkan bahwa media pembelajaran video interaktif berbasis Power Director ini efektif digunakan dalam meningkatkan pemahaman siswa dalam menyelesaikan masalah luas segitiga. Selain dapat meningkatkan hasil belajar, penggunaan media pembelajaran berbasis Power Director ini juga dapat meningkatkan minat belajar siswa. Siswa yang diajar menggunakan menggunakan media pembelajaran berbasis Power Director memiliki rata-rata minat belajar matematika yang tinggi dibanding siswa yang diajar tanpa menggunakan media pembelajaran berbasis Power Director (Rajaguguk, 2011).

Kekurangan yang dirasakan oleh peneliti dalam penelitian ini, sehingga menyebabkan hasil penerapan media ini tidak efektif $100 \%$ adalah karena pemahaman awal konsep matematis siswa masih kurang dapat menggambarkan kemampuan siswa secara optimal, pertama adalah keterbatasan waktu penelitian yang kurang maksimal, kedua, karena pembelajaran dilakukan secara daring, proses keaktifan tanya jawab dan pemberian pertanyaan-pertanyaan tidak bisa dilakukan. Selain itu, ada siswa yang kurang termotivasi karena keadaan pembelajaran daring, mereka merasa bosan terhadap pemberian tugas sehingga menghambat dalam proses penilaian. Faktor penghambat lain juga disebabkan karena faktor jaringan dan perhatian orangtua terhadap proses belajar anak (Putria et al., 2020). 
Lialy Sari menyebutkan bahwa video pembelajaran dapat dijadikan sebagai sumber belajar bagi siswa serta sebagai motivasi dan inovasi dalam proses pembelajaran bagi guru (Ilsa et al., 2021). Hasil pengembangan media pembelajaran video interaktif berbasis Power Director valid dan efektif diterapkan kepada siswa dalam memahami konsep serta menyelesaikan soal luas segitiga.

\section{SIMPULAN}

Berdasarkan hasil dan pembahasan penelitian, dapat disimpulkan bahwa: pertama, berdasarkan hasil validasi dari ahli media menunjukkan bahwa media pembelajaran video berbasis Power Director pada materi luas segitiga adalah valid, dengan nilai kevalidan media sebesar 3,02 dan nilai kevalidan materi sebesar 3,7. Kedua, ada peningkatan nilai siswa yang menggunakan media pembelajaran video interaktif berbasis Power Director efektif dapat meningkatkan kemampuan pemecahan masalah siswa pada materi luas segitiga. Hal ini dapat dilihat dari uji beda yang menunjukkan ada perbedaan yang signifikan nilai hasil tes kelas kontrol dan eksperimen dengan taraf signifikansi sebesar 0,001 $<0,05$ dalam menyelesaikan soal luas segitiga.

\section{DAFTAR PUSTAKA}

Cahdriyana, R. A., \& Richardo, R. (2020). Berpikir Komputasi Dalam Pembelajaran Matematika. LITERASI (Jurnal Ilmu Pendidikan), 11(1), 50. https://doi.org/10.21927/literasi.2020.11(1).50-56.

Elsyam, F. G., Safitri, S., \& Susanti, R. (2019). Pengembangan Media Pembelajaran Berbasis Program Cyberlink Power Director pada Mata Pelajaran Sejarah di Sekolah Menengah Atas. Universitas Sriwijaya. repository.unsri.ac.id.

Fathoni, A. R., \& Budiman, E. (2017). Media Pembelajaran Ipa Pokok Bahasan Sistem Pencernaan Makanan Sesuai Standar Kompetensi. 1(1). https://doi.org/10.31227/osf.io/qp2d7.

Hobri. (2010). Metodologi Penelitian Pengembangan (Aplikasi pada Penelitian Pendidikan Matematika). Pena Salsabila. 
I Made Tegeh dan I Made Kirna (2010). Metode Penelitian Pengembangan Pendidikan. Universitas Pendidikan Ganesha.

Ilsa, Aulya, Farida, F., \& Harun, M. (2021). Pengembangan Video Pembelajaran dengan Menggunakan Aplikasi Power Director di Sekolah Dasar. Jurnal Basicedu, 5(1), 288-300.

Muhasim. (2017). Pengaruh Tehnologi Digital Terhadap Motivasi Belajar Peserta Didik. Palapa: Jurnal Studi Keislaman Dan Ilmu Pendidikan, 5(2), 53-57. http://marefateadyan.nashriyat.ir/node/150.

Nomleni, F. T., \& Manu, T. S. N. (2018). Pengembangan Media Audio Visual dan Alat Peraga dalam Meningkatkan Pemahaman Konsep dan Pemecahan Masalah. Scholaria: Jurnal Pendidikan Dan Kebudayaan, $8(3)$, 219-230. https://doi.org/10.24246/j.js.2018.v8.i3.p219-230.

Nurfa, A. (2012). Penggunaan Alat Peraga Sistem Pernapasan Manusia Pada Kualitas Belajar Siswa SMP Kelas VIII. IV(1), 8-9.

Nurrita, T. (2019). Development of circle learning media to improve student learning outcomes. Journal of Physics: Conference Series, 1321(2), 171-187. https://doi.org/10.1088/1742-6596/1321/2/022099

Putria, H., Maula, L. H., \& Din Azwar Uswatun. (2020). Analisis Proses Pembelajaran dalam Jaringan (DARING) Masa Pandemi Covid-19 pada Guru Sekolah Dasar. Jurnal Basicedu, 4(4), 861-872.

Rajaguguk, W. (2011). Perbedaan Minat Belajar Siswa Dengan Media Komputer Program Cyberlink Power Director dan Tanpa Media Komputer pada Pokok Bahasan Kubus dan Balok di Kelas VIII SMP Negeri 1 Hamparan perak Tahun Ajaran 2009/2010. Jurnal Pendidikan Matematika, 5(2), 205-220. 
126 | Firdaus dan Sholihah: Pengembangan Media Pembelajaran Video 